\title{
The Relationship of Dental Perception and Orthodontic Treatment Need Based on Dental Aesthetic Index of SMA Negeri 15 Medan Student
}

\author{
Agnese Putri Pratiwi, Mimi Marina Lubis \\ Department of Orthodontic \\ Faculty of Dentistry, University of Sumatera Utara \\ Medan, Indonesia \\ mimimlbs@yahoo.com, agneseputri@yahoo.com
}

\begin{abstract}
Malocclusion is a form of occlusion that is irrelevant to the acceptable normal standard form of occlusion. Dental Aesthetic Index (DAI) is a malocclusion index that has been accepted and used by WHO as a simple and valid method. The purpose of this study is to determine the relationship of dental perception and orthodontic treatment need based on DAI in SMA Negeri 15 Medan students. This is a descriptive analytic study with cross sectional approach with 100 subjects meeting the criteria of inclusion and exclusion. The dental perception is examined by using a questionnaire and the orthodontic treatment need is obtained by analyzing study models. The result showed that $29 \%$ of sample and bad perception and $71 \%$ had good perception. The distribution of orthodontic treatment need based on DAI is $55 \%$ with no/slight treatment need, $27 \%$ with elective treatment need, $9 \%$ with highly desirable treatment need and $9 \%$ with mandatory treatment need. It is concluded that there is a significant relationship between dental perception and orthodontic treatment need based on DAI.
\end{abstract}

Keywords-dental perception, dental aesthetic index, orthodontic treatment

\section{INTRODUCTION}

Dental appearance is an important factor increasing the attractiveness of an individual in social interaction. Several factors affecting the overall dental appearance are color, shape, and position of the teeth, especially the anterior teeth. An aesthetic smile is related to color, size, shape, and position of the teeth, the upper lip position, and the visibility of teeth and gingiva. Although each factors can be considered individually, all factors should act together to create harmonization and symmetry to achieve the desirable aesthetic effect $[1,2]$

The misalignment of the teeth caused by the malposition of the teeth, which is the wrong teeth position in each jaw position. Malposition of the teeth will cause malrelation, which is the mistake of the relationship between teeth in different jaws. Furthermore, such condition can lead to malocclusion, which is the deviations from normal occlusion.
Malocclusions can occur due to dental disorders (dental), jawbone (skeletal), the combination between teeth and jaw (dento-skeletal) and also due to muscular disorders (muscular) [3,4]

In some population, misalignment of teeth is not considered as a significant condition requiring any treatment, but in other group of population, the demand for orthodontic treatment is very high. Several studies showed that most people is motivated to undergo orthodontic treatment due to their lack of good perception about teeth, and their bad psychology condition caused by malocclusion. Other study showed that the malocclusion and its treatment did not have consistent effects on individuals. The different results could be due to various interpretations of physical and psychology condition, different social influences, and lack of standard to measure the life quality of each individual [1].

Malocclusion, particularly in the anterior, is usually noticeable and might cause bad social reaction and selfconcept. According to Onyeaso et al, (cit. Khan and Fida, 2008) more than $40 \%$ subjects were reported to be less confident due to the present of malocclusion which limited their daily activities, such as laughing in public, meeting up with friends, and building personal relationships. The dental and oral health condition could affect one's confidence, causing awkwardness in social environment and degradation of psychosocial health [4].

According to the report of National Basic Health Research (Riskesdas) in 2013, North Sumatera Province experiencing the dental and mouth problems as many as $19.4 \%$ [5]. According to Oktavia's research in high school students in Medan showed that the prevalence of malocclusion is still high, which is $60.5 \%$ [6]. With the high prevalence of malocclusion, treatment is necessary to restore physical and mental functioning. Several malocclusion indices have been developed and have been used for diagnostic, classification, epidemiology of data collection, recording of care needs and assessment of treatment success [7]. 


\section{MATERIALS AND METHODS}

This is an analytic descriptive study with cross sectional approach to determine the relationship of the self-perception of dental appearance and the orthodontic treatment needs based on Dental Aesthetic Index on SMA Negeri 15 Medan students. The study is conducted for 6 months, between October 2016 - April 2017, in SMA Negeri 15 Medan.

SMA Negeri 15 Medan has a total of 1175 students. The number of samples was calculated by using a formula of categorical analytic samples. As much as 100 subjects were then selected by using simple random sampling method. All samples must meet the inclusion criteria.

\section{RESULTS}

Table I showed distribution of dental perception of 100 subjects based on gender shows that good perception level is higher in male subjects, with 39 samples $(54.9 \%)$, than in female subjects, with 32 samples $(45.1 \%)$. The table shows that bad perception level is 9 samples (31\%) in male subjects and 20 samples $(69 \%)$ in female subjects.

TABLE I. DENTAL PERCEPTION DISTRIBUTION OF SMA NEGERI 15 MEDAN'S STUDENTS

\begin{tabular}{|c|c|c|c|c|c|}
\hline No & Perception & & Male & Female & TOTAL \\
\hline 1 & $\begin{array}{c}\text { Bad } \\
\text { Perception }\end{array}$ & $\begin{array}{c}\text { Frequency } \\
(\mathrm{n})\end{array}$ & 9.0 & 20.0 & 29.0 \\
\cline { 3 - 6 } & $\begin{array}{c}\text { Percentage } \\
(\%)\end{array}$ & 31.0 & 69.0 & 100.0 \\
\hline 2 & $\begin{array}{c}\text { Good } \\
\text { Perception }\end{array}$ & $\begin{array}{c}\text { Frequency } \\
(\mathrm{n})\end{array}$ & 39.0 & 32.0 & 71.0 \\
\cline { 2 - 6 } & $\begin{array}{c}\text { Percentage } \\
(\%)\end{array}$ & 54.9 & 45.1 & 100.0 \\
\hline \multicolumn{6}{|c|}{ TOTAL } \\
\hline
\end{tabular}

Table II exhibited the frequency and percentage of all subjects which were impression recorded in SMA Negeri 15 Medan. This table showed the highest frequency and percentage of $55 \%$ in the category of no or slight treatment need (normal or minor malocclusion), followed by $27 \%$ in the category of elective treatment need (definite malocclusion), $9 \%$ in the category of highly desirable treatment need (severe malocclusion) and $9 \%$ in the category of mandatory treatment need (very severe, handicapping malocclusion).

TABLE II. THE DISTRIBUTION OF ORTHODONTICS TREATMENT NEEDS ON SMA NEGERI 15 MEDAN'S STUDENTS.

\begin{tabular}{|c|c|c|c|c|}
\hline No & $\begin{array}{l}\text { Treatment } \\
\text { Needs }\end{array}$ & Maloclussion & $\begin{array}{l}\text { Frequency } \\
\text { (n) }\end{array}$ & $\begin{array}{c}\text { Percentage } \\
(\%)\end{array}$ \\
\hline 1 & $\begin{array}{l}\mathrm{No} / \text { slight } \\
\text { treatment need }\end{array}$ & $\begin{array}{c}\text { Normal/ } \\
\text { minor } \\
\text { malocclusion }\end{array}$ & 55.0 & 55.0 \\
\hline 2 & $\begin{array}{c}\text { Elective } \\
\text { treatment need }\end{array}$ & $\begin{array}{c}\text { Definite } \\
\text { malocclusion }\end{array}$ & 27.0 & 27.0 \\
\hline 3 & $\begin{array}{c}\text { Highly } \\
\text { desirable } \\
\text { treatment need }\end{array}$ & $\begin{array}{c}\text { Severe } \\
\text { malocclusion }\end{array}$ & 9.0 & 9.0 \\
\hline 4 & $\begin{array}{c}\text { Mandatory } \\
\text { treatment need }\end{array}$ & $\begin{array}{l}\text { Very severe } \\
\text { malocclusion }\end{array}$ & 9.0 & 9.0 \\
\hline \multicolumn{3}{|c|}{ TOTAL } & 100.0 & 100.0 \\
\hline
\end{tabular}

Table III showed the relationship of dental perception and orthodontic treatment needs. Among 29 subjects with bad perception, 9 subjects (31\%) have normal or have minor malocclusion, 8 subjects $(27.6 \%)$ have definite malocclusion, 7 subjects $(24.1 \%)$ have severe malocclusion and 5 subjects $(17.2 \%)$ have with very severe malocclusion. Among 71 subjects with good perception, 46 subjects $(64.8 \%)$ have normal or have minor malocclusion, 19 subjects $(26.8 \%)$ have with definite malocclusion, 2 subjects $(2.8 \%)$ have severe malocclusion, and 4 subjects $(5.6 \%)$ have very severe malocclusion. The Chi-square test showed significant relationship of dental perception and orthodontic treatment needs $(\mathrm{P}<0.05)$.

TABLE III. THE RELATIONSHIP OF DENTAL PERCEPTION AND ORTHODONTICS TREATMENT NEED ON SMA NEGERI 15 MEDAN STUDENTS

\begin{tabular}{|c|c|c|c|c|c|}
\hline & $\begin{array}{c}\text { Normal/ } \\
\text { minor } \\
\text { malocclusion }\end{array}$ & $\begin{array}{c}\text { Definite } \\
\text { malocclusion }\end{array}$ & $\begin{array}{c}\text { Severe } \\
\text { malocclusion }\end{array}$ & $\begin{array}{c}\text { Very severe } \\
\text { malocclusion }\end{array}$ & \\
\hline $\begin{array}{c}\text { Bad } \\
\text { Perception } \\
(\%)\end{array}$ & 31.0 & 27.6 & 24.1 & 17.2 & \\
\cline { 1 - 3 } $\begin{array}{c}\text { Good } \\
\text { Perception } \\
(\%)\end{array}$ & 64.8 & 26.8 & 2.8 & 5.6 & \\
\hline
\end{tabular}

\section{DISCUSSION}

This study was conducted on 100 students of SMA Negeri 15 Medan, male and female who met the criteria of inclusion and exclusion. This study aimed to find the relationship of dental perception and the orthodontic treatment needs based on Dental Aesthetic Index (DAI).

Table I shows 71 students (71\%) with good dental perception and 29 students $(29 \%)$ with bad dental perception. Ullal et al conducted a study on 103 students, aged 13-16 years old in Annamalai Nagar, Chidambaram. The study resulted in 65 students $(63.1 \%)$ with good dental perception and 35 students (33.9\%) with bad dental perception [8]. The study conducted by Dikson et al on 138 models of 18-to-21year-old in Brazil, reported similar results, 110 subjects (79.7\%) with good dental perception and 28 subjects (20.3\%) with bad dental perception [9].

Table II shows 55 students (55\%) with no or slight treatment need (normal/minor malocclusion), 27 students $(27 \%)$ with elective treatment need (definite malocclusion), 9 students (9\%) with highly desirable treatment need (severe malocclusion), and 9 students (9\%) with mandatory treatment need (very severe, handicapping malocclusion). The study by Fadil and Trefa on 100 study models of patients aged 13-22 years old at the orthodontic clinic in University of Sulaimani, Iraq showed similar results. It showed $46 \%$ subjects with no or slight treatment need, $29 \%$ subjects with elective treatment need, $10 \%$ subjects with highly desirable treatment need, and $15 \%$ subjects with mandatory treatment need [10]. Another study conducted by Aarathi et al, on 705 children aged 13-15 years old in Bangalore, India, showed that $21.7 \%$ subjects have no or slightly treatment need, $28.9 \%$ subjects have elective treatment need, $28.5 \%$ subjects have highly desirable treatment need and $20.9 \%$ 
subjects have mandatory treatment need [11]. The different results might be due to differences in the number of sample, the group of age, and mostly, the category of no or slight treatment need.

Table III shows a significant relationship of dental perception and the orthodontic treatment need based on DAI, using chi-square Pearson test. A similar study by Ullal et al on 103 subjects in Chidambaram also resulted in a significant relationship of dental perception and orthodontic treatment needs [8]. Another study by Dickson et al on 138 samples in Brazil also showed significant relationship of dental perception and orthodontic treatment needs based on DAI [9].

One drawback of this study is the subjectivity of the questionnaire. Each subject would answer based on their opinion about their own dental appearances, which means that subjects might find normal dental appearances to be unsatisfactory, thus, lowering their personal dental perception. Another drawback of using DAI index is that there are more scores to evaluate the anterior dentition and fewer score to evaluate the posterior dentition

As a conclusion, the distribution of dental perception on SMA Negeri 15 students is 29 subjects (29\%) with bad perception, and 71 subjects $(71 \%)$ with good dental perception. The distribution of orthodontic treatment needs based on Dental Aesthetic Index (DAI) on SMA Negeri 15 students is 55 students (55\%) with no or slightly treatment need (normal/minor malocclusion), 27 students $(27 \%)$ with elective treatment need (definite malocclusion), 9 students (9\%) with highly desirable treatment need (severe malocclusion) and 9 students (9\%) with mandatory treatment need (very severe, handicapping malocclusion). The results show significant correlation of dental perception and orthodontic treatment needs based on Dental Aesthetic Index (DAI)

\section{REFERENCES}

[1] M.M. Tin-Oo, N. Saddki, N. Hasan, "Factors influencing patient satisfaction with dental appearance and treatments they desire to improve aesthetics," BMC Oral Health, vol. 11(1), pp. 6-13, 2011

[2] V. Singh, A. Hamdan, P. Rock, "The perception of dental aesthetics and orthodontic treatment need by 10- to 11-year-old children," European Journal Orthod., vol. 34(5), pp. 646-651, 2012.

[3] H. Sulandjari, Buku ajar ortodonsia I KGO I, $1^{\text {st }}$ ed., Indonesia: Yogyakarta, 2008, pp. 6.

[4] D.F. Paula Jr, et al., "Effect of anterior teeth display during smiling on the self-perceived impacts of malocclusion in adolescents," Angle Orthod., vol. 81(3), pp. 540-545, 2011.

[5] U. Hagg, C. McGrath, M. Zhang, "Quality of life and orthodontic treatment need related to occlusal indices," Dental Buletin, vol. 12, pp. 8-12, October 2007.

[6] D. Uzuner, E. Kaygisiz, L. Taner, et al., "Angle's classification versus dental aesthetic index in evaluation of malocclusion among Turkish orthodontic patients," Journal of Dental Applications, vol. 2(3), pp. 168-169, 2015.

[7] C. Shetty, S. Madhukar, K. Nayak, et al., "The correlation of occlusal indices with patients perceptions on aesthetics, function, speech and orthodontic treatment need," Journal of Dental Sciences \& Research, vol. 1(1), pp. 23.

[8] U.A. Nayak, J. Winnier, S. Ruseph, "The relationship of denta aesthetic index with dental appearance, smile and desire for orthodontic correction," International Journal of Clinical Pediatric Dentistry, vol. 2(2), pp. 8, 2009.

[9] D. Claudino, J. Traebert, "Malocclusion, dental aesthetic selfperception.and quality of life in a 18 to 21 year-old population: a cross section study," BMC Oral Health, vol. 13(1), pp. 1-6, 2013.

[10] F.A. Kareem, T.M.A. Mahmood, "Psychological impact of dental aesthetics for Kurdish adolescents seeking orthodontic treatment," Iranian Journal of Orthodontics, vol. 2(1), pp. 4656,2013

[11] A. Vijayan, J. Jayarajan, S.S. Hiremath, B.N. Fathima, F. Shaj, T.T. Edathotty, "Relationship between index of complexity, outcome and need and dental aesthetic index and perception of malocclusion in school children of Bangalore City," I. J. Pre. Clin. Dent. Res., vol. 1(4), pp. 58-64, 2014. 